\title{
COVID-19 update: Covid-19-associated coagulopathy
}

\author{
Richard C. Becker ${ }^{1}$
}

Published online: 15 May 2020

(c) Springer Science+Business Media, LLC, part of Springer Nature 2020

\begin{abstract}
We are too much accustomed to attribute to a single cause that which is the product of several, and the majority of our controversies come from that.
\end{abstract}

Marcus Aurelius

The Covid-19 pandemic has introduced an array of organspecific and systemic phenotypes- some previously observed in viral infections, including severe acute respiratory syndrome (SARS) and others that appear to be unique to SARScoronavirus $(\mathrm{CoV})-2$. Rapidly emerging information from clinical observations, autopsy-based findings, extrapolations from in vitro and ex vivo studies and dynamic modeling are informing management guidelines; however, many questions remain unanswered and clinical trials that are required to provide evidence have not been completed in most areas. Among the many questions that require careful thought, reflection and investigation are the mechanism(s) underlying the development of a systemic coagulopathy and acquired thrombophilia characterized in a majority of cases by a proclivity for venous, arterial and microvascular thrombosis.

The following review summarizes emerging insights into the pathobiology, mechanism(s), diagnosis, management, foundations for research and either planned or ongoing clinical trials for Covid-19-associated coagulopathy.

\section{Venous and arterial thrombosis in Covid-19 infection}

Klok et al. [1] evaluated the occurrence of venous and arterial thrombotic events, including deep vein thrombosis (DVT), pulmonary embolism (PE), ischemic stroke,

Richard C. Becker

Richard.becker@uc.edu

1 Heart, Lung and Vascular Institute, University of Cincinnati College of Medicine, 231 Albert Sabin Way, Cincinnati, OH 45267, USA myocardial infarction and systemic arterial events in 184 patients with Covid-19 pneumonia admitted to the intensive care unit (ICU). All patients received standard thromboprophylaxis (Nadroparin 2850 to 5700 IU per day based on body weight). The composite incidence of thrombotic events was $31 \%$. Venous thromboembolic events were the most common (27\%) and a majority were PEs. Independent predictors of thrombotic events were increased age and evidence on screening blood tests for a coagulopathy (prothrombin time $[\mathrm{PT}]>3 \mathrm{~s}$ above the upper limit of normal $[\mathrm{ULN}]$ ), activated partial thromboplastin time [APTT] $>5 \mathrm{~s}$ above the ULN; adjusted hazard ratio 4.1, 95\% CI 1.9-9.1). None of the patients experiencing thrombotic events met strict criteria for disseminated intravascular coagulation (DIC).

Tang et al. reported on abnormal coagulation parameters and poor prognosis in 183 consecutive patients with Covid-19 pneumonia [2]. Those who did not survive their illness compared with survivors had higher D-dimer levels, fibrin(ogen) degradation products (FDP) and longer PT and APTT values. Abnormal coagulation parameters were evident early after hospitalization and in some patients, fibrinogen concentrations and antithrombin activity decreased over time.

The same investigators [3] reported in 445 patients that anticoagulant therapy, primarily with low molecular weight heparin (LMWH) administered for 7 days or longer was associated with a lower 28-day morality when administered to patients with a sepsis-induced coagulopathy (SIC) score $\geq 4$ or a D-dimer value greater than 6 times the ULN. The SIC score is derived from the platelet count, PT ratio, FDPs, systemic inflammatory response syndrome (SIRS) score and a sequential organ system failure assessment.

Helms et al. [4] reported the occurrence of thrombotic events among 150 patients with Covid-19 and acute respiratory distress syndrome (ARDS) admitted to the ICU. Propensity matching was undertaken to determine the risk of thromboembolic events for patients with Covid-19 and those with non-Covid-19 infection-associated ARDS. Twenty-five patients (16.7\%) experienced a PE; among 29 
patients undergoing renal replacement therapy 28 (96.6\%) experienced circuit clotting and of 12 patients requiring extracorporeal membrane oxygenation (ECMO) for refractory hypoxemia, three thrombotic circuit occlusions (in two patients) occurred. Lupus anticoagulants were detected in 50 of 57 patients tested (87.7\%). In patients with non-Covid-19 infection-associated ARDS, 2.1\% experienced a PE. The investigators also reported that patients with Covid-19-associated ARDS did not develop DIC and had markedly elevated circulating levels of Von Willebrand factor (VWF) antigen, VWF activity and factor VIII [5].

Perhaps one of the least expected and most striking complications of Covid-19 is acute large vessel occlusion with ischemic stroke in patients less than 50 years of age [6]. Among the 5 patients reported by Oxley et al., the youngest was 33 years of age and the mean NIHSS score was 17 , consistent with severe large vessel stroke. In the original cases reported from Wuhan China, stroke was seen in $5 \%$ of patients $[7,8]$; however, the youngest patient in the Wuhan experience was 55 years.

While endocardial thrombosis has been reported in the hearts of decedents with Covid-19 representing a possible nidus for cardioembolic events [9], large vessel arterial thrombosis in situ would support wide-scale endotheliitis involving moderate-to-large arteries. This would have important near-term and long-term implications to include late-onset arterial stenosis, aneurysm and pseudo-aneurysm formation with a need for screening after recovery.

\section{The SARS-CoV-2 virus: characteristics, unique properties and thrombosis risk}

\section{SARS-CoV-2 virus}

Coronaviruses belong to the subfamily Coronavirineae in the family of coronavitidae of the order nidovirales (reviewed in Becker) [10]. The genome is a singlestranded positive-sense RNA ( $30 \mathrm{~kb})$ with a $5^{\prime}$ cap structure and a 3'-poly-A tail. Homotrimers of S proteins make up the spikes on the virus surface and enable binding to host receptors. Coronaviruses contain at least 6 open-read frames (ORFs) that encode primary structural proteins that include spike (S), membrane (M), envelope (E) and nucleocapsid $(\mathrm{N})$. S proteins are responsible for attachment to host receptors. M proteins contain transmembrane domains that contribute to virus shape and binding to the nucleocapsid. The $\mathrm{E}$ protein is involved with virus assembly and pathogenesis. The $\mathrm{N}$ protein packages and encapsulates the genome into virions and also antagonizes silencing RNA (reviewed in Becker) [10].

\section{Binding to Host Cells}

The available information suggests that SARS-CoV-2 binds to host cells via the angiotensin converting-enzyme (ACE) 2 receptor ( $\mathrm{R}$ - - a metallopeptidase (reviewed in Becker) [10]. ACE2 mRNA is present in all major organs, however, its protein expression is greatest in several key organs and locations that play important roles in the initiation of infection and its phenotypic expression, including venous, arterial and microvascular thrombosis. The major organs include the nasopharynx, oropharynx, lungs, stomach, small intestine, spleen, liver, kidney and brain with binding to ACE2 receptors on epithelial, endothelial and enterocytic cells. The density of ACE2R is particularly high in the lungs, heart, veins and arteries [11].

Hamming et al. [11] used human tissues obtained from patients undergoing diagnostic biopsies or surgery, unused organs procured for transplantation purposes and during autopsies. They found a high density of ACE2R expression in endothelial cells from small and large arteries and veins in all tissues. They also found ACE2R expression in arterial smooth muscle cells in some organs, specifically the brain. This observation may have relevance in the complication of acute ischemic stroke discussed previously.

Chen et al. (Chen, 2020 \#9069\}) developed a single cell atlas of the adult human heart to determine the distribution and density of ACE2R expression. They identified a high level of expression (RNA and protein) in pericytes and postulated that viral entry and injury may in turn cause capillary endothelial cell injury and microvascular dysfunction. ACE2R expression in human hearts was identified across eight major cell types, including cardiomyocytes, endothelial cells, macrophages, fibroblasts, pericytes, smooth muscle cells, T cells and neuron-like cells. The potential role of pericytes in the Covid-19-associated thrombosis will be discussed in greater detail in a section to follow.

While the question remains whether direct cellular invasion is both necessary and sufficient for end-organ injury, observations derived from hospital based and epidemiologic data show phenotypic variability, ranging from complete absence of symptoms (asymptomatic carriers) to cardiogenic shock, refractory respiratory failure and death. Viral load, immunologic response and pre-existing conditions likely contribute to organ damage and overall outcomes.

\section{Viremia and viral load}

The original patient cohort of what ultimately was discovered to be SARS-CoV-2 cited a $15 \%$ incidence of viremiaRNAemia [7]. Prior experiences with highly pathogenic 
virus outbreaks may offer insights into the distribution of Covid-19 infections. The Avian influenza H7N9 virus caused human viremias and in a murine model of virus infection, live virus was detectable in serum. Infected A549 cells secreted exosomes containing the entire viral genome representing a potential mechanism for extrapulmonary infection. High serum levels of cytokines were detectable in patients and test animals $[12,13]$.

Viral load dynamics and disease severity were reported by Zheng et al. [14]. From 96 consecutive patients, RNA viral load was measured in respiratory, stool, serum and urine samples (total number of samples 3497). RNA was detected in the stool of $55(59 \%)$ and in the serum of 39 $(41 \%)$ of patients. All patients had SARS-CoV-2 detected in sputum and saliva samples. Only one patient had a positive urine sample. The median duration of RNA detection in the stool was 22 days (IQR 17-31 days); in the sputum and saliva, 28 days (IQR 13-29 days) and in the serum 16 days (IQR 18-21 days). Virus persistence correlated with disease severity.

$\mathrm{Hu}$ et al. determined the time to negative conversion of viral RNA in patients hospitalized with Covid-19 infection [15]. The median time from the first day of a positive RNA test to consecutive negative tests was 14 (IQR 10-18) days. From a patient cohort of 59 patients, 10 patients had intermittent negative culture results from the same site(s).

SARS-CoV-2 viremia correlates with Covid-19 infection severity and acuity [16].

\section{Potential mechanism(s) for Covid-19-associated thrombosis}

Virchow's triad that includes abnormalities of blood flow, vascular injury and abnormalities within the circulating blood is a time-honored pathological construct that provides a foundation for understanding and investigating thrombosis whether it occurs in arteries, veins or the microvascular circulation. While each of the three conditions are met in a majority of conditions, it is important to recognize that the contributions can vary by conditions and across vascular beds. This construct will be discussed in further detail in subsequent sections.

\section{Autopsy series in decedents with Covid-19 infection}

The Covid-19 pandemic has impacted people worldwide. Several cities have been particularly hard-hit in the United States. Autopsies were performed on four decedents from New Orleans, LA. Each tested positive for SARS-CoV-2 by real-time polymerase chain reaction (RT-PCR) and had laboratory values notable for elevated fibrinogen, ferritin, PT and D-dimer levels at the time of hospitalization [9]. The following observations were made at autopsy: the pulmonary arteries at the hilum were free of thromboembolism, there was diffusely edematous lung parenchyma, hemorrhage in the peripheral parenchyma ( 3 of 4 decedents), small and firm thrombi in sections of the peripheral parenchyma and absence of gross inflammation. Microscopic findings on histology included: mild-to-moderate lymphatic infiltrates (predominately in the interstitial space), CD4+lymphocytes aggregated around small blood vessels that contained platelets and small thrombi, desquamated type- 2 pneumatocytes within the alveolar spaces, small vesicles believed to represent viral inclusions, thickening of alveolar capillaries with fibrin thrombi, entrapped neutrophils and $\mathrm{CD} 1^{+}$megakaryocytes (Fig. 1). The hearts were notable for cardiomegaly and right ventricular dilation. Coronary artery thrombosis was not seen in any of the four decedents on histologic examination, however, there was scattered individual myocyte necrosis with adjacent lymphocytes.

\section{More on pericytes}

Pericytes and perivascular cells are present on the abluminal surface of micro vessels where they are embedded in the basement membrane [17]. Gap junctions provide a portal of direct communication between endothelial cells and pericytes through which ions, paracrine proteins and small molecules can be exchanged for the purpose of signaling and maintaining vascular integrity. Pericytes play many important roles in vascular homeostasis, ranging from vascular repair to regulation of vascular tone; however, they play a particularly important role in states of inflammation where they cover gap junctions (reviewed in Sims [18]. Abnormalities within pericytes or degeneration cause tissue injury and metabolic changes that can also be detrimental to vital organs.

Magro et al. [19] reported on the autopsy findings from five decedents with severe Covid-19 infections and ARDS. They identified a pattern of tissue damage involving the lung and skin consistent with complement-mediated microvascular injury. There was marked deposition of C5b-9, C4d and Mannan-binding lectin serine protease (MASP)-2 supporting a generalized activation of alternative and lectin-based pathways. Similar to other autopsy studies, they described pauci-inflammatory capillary injury with mural and luminal fibrin deposition. In addition, hallmarks of classic ARDS with diffuse alveolar damage, hyaline membranes, inflammation and type II pneumocyte hyperplasia were not prominent findings. The skin lesions were characterized as a pauciinflammatory thrombogenic vasculopathy.

The contribution of neutrophil extracellular traps (NETs) to the phenotypic expression and end-organ injury among patients with COVID-19 is an important area for consideration. Barnes et al. summarized their findings from an 

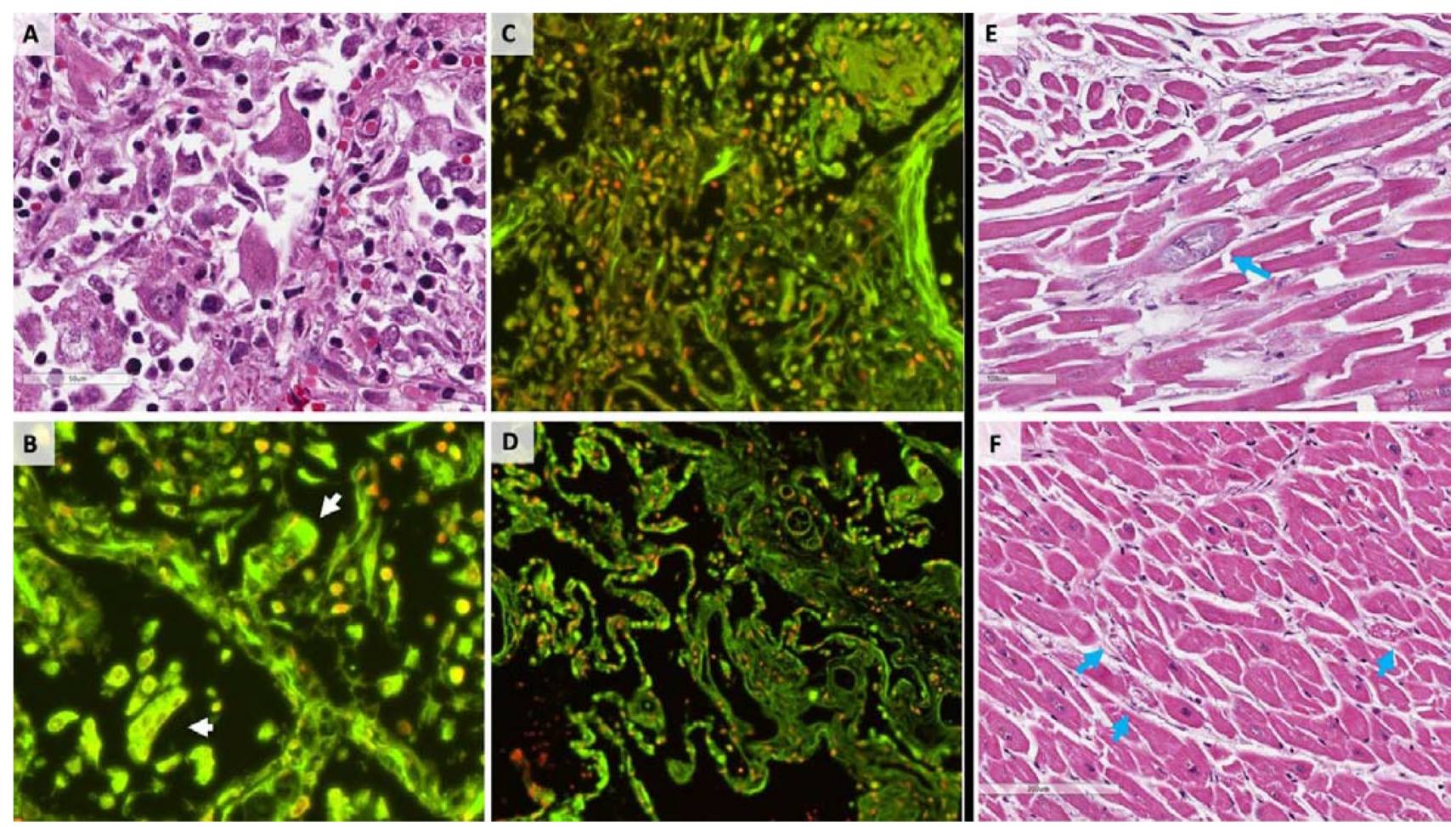

Fig. 1 Shows a damaged alveolus with enlarged nuclei and cytologic atypia (a) with abundant DNA (red) and RNA (green) within tissue sections and virally infected cells with an abundance of extracellular DNA and RNA in the cytoplasm (b) co-localized with fibrin and extracellular nucleic acids (c). d is a control lung specimen. Panels e

autopsy series and developed a working hypothesis to integrate pulmonary infection, cytokines and thrombosis [20]. They observed the following pathological features in three descendants: neutrophil infiltration in pulmonary capillaries, acute capillaritis within fibrin deposition, extravasation of neutrophils into the alveolar space and neutrophilic mucositis.

Observations shared by pathologists around the world point to a very unique picture in decedents with Covid-19 infection: macro and microvascular thrombosis with the former consisting of both red (erythrocytes, leukocytes, fibrin) and white (platelets and fibrin) and the latter platelet-fibrin micro-thrombi in venules, arterioles and capillaries in all major organs including mesenteric fat, minimal evidence of microangiopathy, intravascular megakaryocytes, endocardial thrombi, viral particles in adipocytes and an unusual abundance of platelets in the spleen.

\section{Endotheliitis}

The widescale expression of ACE2 receptors within endothelial cells raises a question of its vulnerability to SARS-CoV-2 binding, membrane fusion and viral entry and $\mathbf{f}$ show focal degeneration of cardiomyocytes. A pathology hallmark of Covid-19 infection is diffuse small vessel (venule, arteriole and capillary) platelet-fibrin thrombosis and intravascular megakaryocytes in all major organs, including the heart, lungs, kidneys, liver and mesenteric fat. From [9] with permission

causing infection and attendant vascular injury and dysfunction. Engineered human blood vessel organoids can be infected with SARS-CoV-2 [21]. This can be blocked by human recombinant soluble ACE2. Varga et al. describe endothelial cell involvement across vascular beds in a small series of descendants with Covid-19 [22]. Accumulation of inflammatory cells and viral inclusions by histology and electron microscopy, respectively, were identified within the endothelium of the heart, small bowel, kidneys, and lungs. In autopsy and surgical tissue specimens there was diffuse lymphocytic endotheliitis and apoptotic bodies (Fig. 2). It is important to consider that apoptosis may not require host cell viral entry, but rather binding to the cell surface and subsequent apoptotic pathway signaling [23].

Reticular inclusions, primarily within vascular endothelial cells are composed of glycoproteins and phospholipids that originate within the rough endoplasmic reticulum in response to interferon (IFN)-1 expression [24]. Viral infections and autoimmune diseases are the most common causes of high IFN-1 expression and reticular inclusions that, in turn, cause endothelial cell injury, dysfunction and prothrombotic gene expression. 

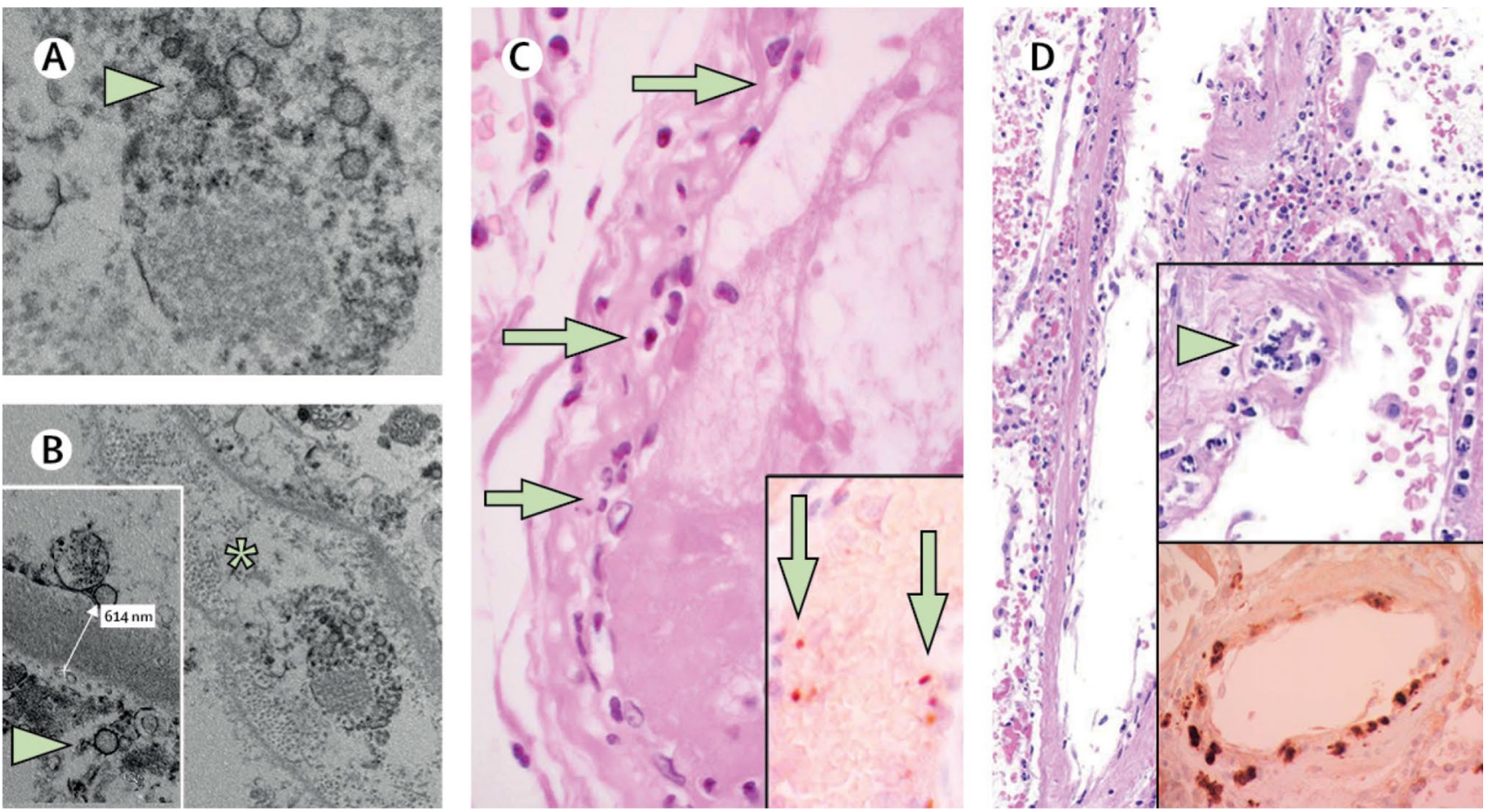

panel d demonstrates apoptotic endothelial cells and mononuclear

Fig. 2 The mechanism(s) underlying a prolonged thrombophilic state following Covid-19 infection are unknown, but may be related to diffuse vascular endothelial cell infection, injury and dysfunction. Viral particles and inclusion bodies are seen within endothelial cells of the glomerular capillary loops (a and $\mathbf{b}$ ); in panel $\mathbf{c}$, inflammatory cells are observed within capillaries serving the small intestine, while

\section{Hyperinflammation}

The profound increase of inflammatory biomarkers in patients with Covid-19 infection and their association with poor clinical outcome has been attributed to an unregulated immune response to a new pathogen-antigen in the form of SARS-CoV-2. While inflammation has been observed in the lungs and other organs, as previously discussed, the pathology community has commented on the relative paucity of inflammation that appears to be less than anticipated for the degree of tissue damage and circulating levels of many cytokines. The specific tissues with inflammation is likely pivotal to understanding clinical phenotypes, including thrombosis and will be discussed in greater detail in a section to follow.

Some clinicians and investigators have raised the question of a hemophagocytic lymphohistiocytosis (HLH)-like syndrome in Covid-19 pneumonia. In classic HLH, there is excessive inflammation often in response to infection andor malignancy resulting from impaired down-regulation of activated macrophages and lymphocytes (reviewed in Jumic [25]. While patients with Covid-19 meet some of the criteria for HLH, there is wide variability that likely reflects a combination of its protean nature, secondary infections cells. The available clinical and pathological evidence, coupled with strong and mature data that supports a relationship between CFRNA, polyphosphate and factor XI activation, raises a logical scientific premise that requires investigation. From [23] with permission

and end-organ failure [26]. Similarly, the broad category of macrophage activation syndrome or secondary HLH has been applied to acknowledge some of the pulmonary findings of Covid-19 pneumonia and concomitant suppression of $\mathrm{CD} 4+\mathrm{T}$ cell interferon- $\gamma$ production that collectively yield a hyper-inflammatory immunosuppressive state [27].

\section{Platelets in Covid-19-associated thrombosis}

Platelets can either protect or promote immune-mediated responses to pathogens [28] (reviewed in Becker) [29]. Platelets bind to a number of different microbes, either through direct interactions, often mediated by platelet $\mathrm{Fc}$ receptors, or indirectly via plasma protein bridges [30]. Similar to agonist-activation, the binding of pathogens can trigger granule cargo release [31] and liberation of "platelet microbial" proteins and peptides, including platelet factor (PF)-4, regulated on activation, normal $\mathrm{T}$ cell expressed and secreted (RANTES), and fibrinopeptide B. Platelets may also play an important role in the clearance of viral pathogens. Platelet interactions with leukocytes trigger recruitment and tissue infiltration necessary for pathogen clearance (reviewed in Guo [32]. In critically ill patients, 
thrombocytopenia correlates with multi-organ failure and death, and a decline in platelet count, even in the absence of overt thrombocytopenia, portends a worse outcome [33]. As mentioned previously, a unique feature of Covid-19 infection is the presence of extramedullary megakaryocytes that actively produce platelets.

\section{NETs as a unifying theme in Covid-19 infection and thrombosis phenotypes}

In response to strong stimulation, neutrophils, and to a lesser degree monocytes and eosinophils, release extracellular traps (ETs), consisting of DNA and histones (Fig. 3) in a process known as NETosis. The process involves histone $(\mathrm{H})$ citrullination (Cit) by peptidylarginine deiminase (PAD)4 , chromatin unwinding, breakdown of nuclear membranes and cytolysis [34, 35]. There is also a vital or "non-lytic" NETosis, wherein nuclear materials (eg. DNA and histones) are released without cellular membrane disruption [36, 37].

Circulating cell-free (cf) nucleic acids are DNA and RNA species present in either serum or plasma. Circulating cfDNA in healthy individuals originates primarily from apoptotic cells and is truncated to small and uniform DNA fragments of 188-200 base pairs. By contrast, cf-DNA released in the setting of infection is the result of cellular and tissue necrosis, apoptosis, autophagy or mitotic catastrophe [38] (Fig. 4).

SARS-CoV-2 is an RNA virus. This may be pathologically and clinically relevant for several reasons. Nakazawa et al. first identified cf-RNA that could initiate coagulation by serving as a cofactor for the auto-activation of factor
VII-activating protease [39]. Kannemeier et al. performed a series of experiments to determine the functional significance of intracellular material exposed to blood following tissue injury. Extracellular RNA was found to activate proteases of the contact system of coagulation, including factors $\mathrm{XI}$ and XII-both of which exhibited strong RNA binding. Administration of RNA provoked a thrombotic response and RNA exposed following vascular injury with ferric chloride $\left(\mathrm{FeCl}_{3}\right)$ was less prothrombotic in mice pre-treated with RNAase. Thus, under conditions characterized by tissue injury, extracellular RNA serves as a template for contact activation-dependent thrombosis [40].

Gajsiewicz et al. [41] investigated the ability of polyphosphates to modulate the contact-mediated pathway of coagulation. They observed that polyphosphates facilitated factor XI activation. Secondary structures of RNA, particularly hair-pin forming oligomers are highly procoagulant. There is an RNA length-contact activation relationship (reviewed in Baker [42], however, even relatively short polyphosphates released from activated platelets accelerate factor $\mathrm{V}$ activation, inhibit the anticoagulant activity of tissue factor pathway inhibitor (TFPI), promote factor XI activation by thrombin, and contribute to the synthesis of thicker fibrin strands that are resistant in fibrinolysis. Extracellular polyphosphates and nucleic acids (RNA and DNA) often co-localize following cellular injury and in highly inflammatory environments.

Tissue NETs cause platelet activation and thrombosis, possibly from NET-associated histones that can induce platelet aggregation through toll-like receptors (TLRs) on platelets and other cells. Platelet signaling activates the major platelet adhesion receptor, integrin $\alpha \operatorname{IIb} \beta 3$, which mediates
Fig. 3 Neutrophil extracellular traps (NETs) consist of extracellular chromatin strands (nucleic acids, DNA) wrapped around histones (nucleosomes) and inter-woven with fibrin strands. NETs are an ideal foundation or template for binding activated platelets, erythrocytes and leukocytes, activating factor XI and generating thrombin for fibrin production

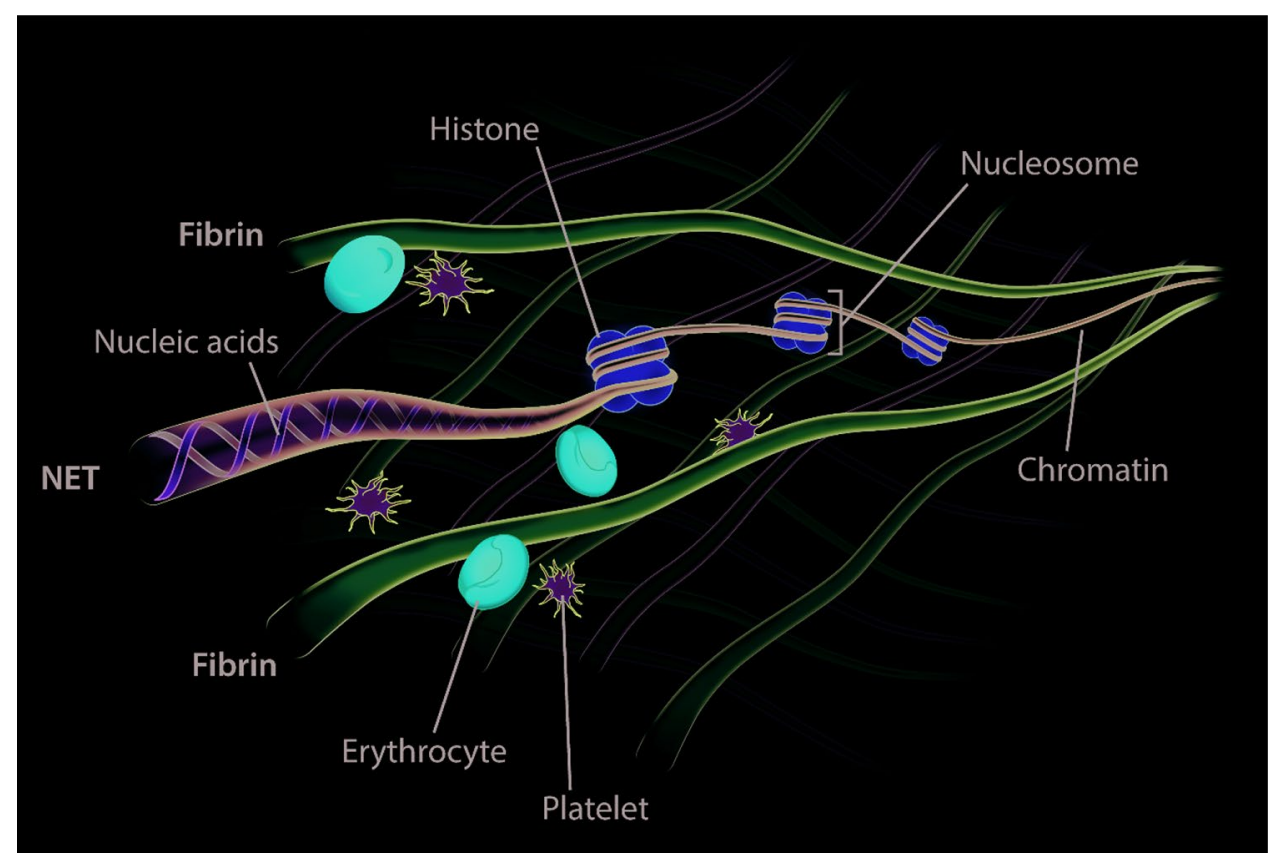


Fig. 4 D-dimer is a fibrin degradation product or small protein fragment present in the peripheral blood after fibrin is formed from fibrinogen (in the presence of thrombin) and subsequently degraded by plasminogen activators. Its name is derived from having $\mathrm{D}$ fragments of the fibrin protein joined by a covalently bound cross-link (factor XIII)

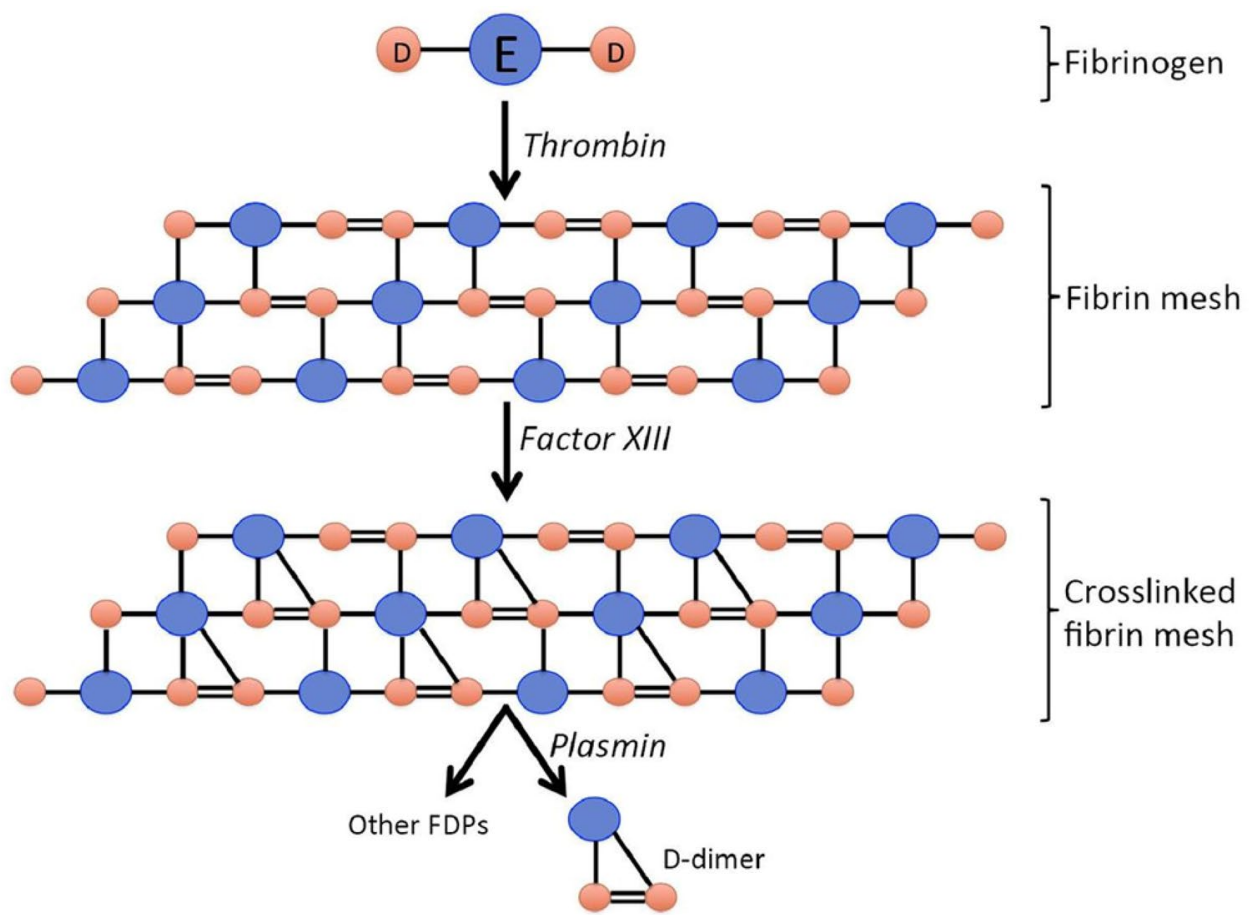

platelet aggregation, as well granule release, phosphatidylserine exposure, FV/Va expression and thrombin generation [43-45]. NETs are recognized as linking inflammation, coagulation and thrombosis both locally and systemically in multiple conditions [46].

Zuo et al. [47] reported high levels of circulating cf-DNA and DNA-myeloperoxidase complexes in patients with Covid-19. The levels correlated with the acuity of illness, inflammatory response and need for mechanical ventilation.

\section{More on the platelet-NET interface}

Platelets play a pivotal role in the recruitment of neutrophils to sites of inflammation as well as their subsequent transendothelial migration. Von Willebrand Factor (VWF) is actively involved in this process. The interaction of platelets and neutrophils, to include NET formation, occurs through several signaling pathways independent of platelet aggregation and thrombosis (reviewed in Pitchford) [48]. Accumulation of platelets and VWF within microvessels is a unifying step for endothelial cell activation, impaired vascular integrity, leukocyte recruitment, trans-endothelial migration, tissue inflammation, and target organ injury [49].

While platelets dissociate from leukocytes during transendothelial migration in high shear stress conditions, platelet-leukocyte complexes can remain intact under low mechanical stress as well [50]. Inflammation and its triggers stimulate the formation of ultra-large VWF fibers that become immobilized on the endothelial cell surface where they are transformed to highly adhesive strings under shear conditions [51].

Platelets contain functional RNA that can be transferred to other cells in a process referred to as horizontal transfer (reviewed in Clancy) [52]. The transfer of platelet cytosolic RNA to nucleated cells increases protein translation and biological effects at the vascular level and, if the recipient cell undergoes trans-endothelial migration, at the tissue level [53]. Platelet micro-vesicles are also an important source of RNA that can be transferred to a variety of cells, including neutrophils, T lymphocytes, monocytes, macrophages and smooth muscle cells (reviewed in Edelstein) [54].

\section{NETs and microvascular thrombosis}

NETs represent part of a continuum of sterile inflammation and thrombosis that can involve all vascular beds, including the microvascular circulation [55-66].

\section{The contribution of Von Willebrand factor}

While NETs "trap" bacteria and other pathogens [67], they can also injure host tissues through the release of proteolytic proteins [68]. Similar processes have been described in the heart. For example, ischemia-reperfusion injury of the myocardium causes an increase in plasma nucleosomes, but in addition, there is abundant neutrophil infiltration at the tissue level and citrullinated histone $\mathrm{H} 3$ at the site of injury. [69, 70]. 


\section{Von Willebrand Factor Kinetics in Covid-19 infection}

Escher et al. identified several unique features in a patient with Covid-19 pneumonia and ARDS [71]. In addition to a continued rise in D-dimer levels, as others have reported, the patient had anti-cardiolipin antibodies (IgM) and $\operatorname{IgM}$ anti- $\beta_{2}$-GPI, a marked increase in VWF antigen, VWF activity ( fourfold above the ULN) and factor VIII levels. The findings are consistent with wide-scale systemic vascular endothelial cell activation.

\section{Covid-19-associated coagulopathy: are the lungs a potential site of origin?}

Covid-19 begins in a majority of symptomatic persons as an upper respiratory tract illness with rhinorrhea, anosmia, cough and fever. In those in whom clinical progression takes place, there is involvement of the lower respiratory tract. The typical features that in parallel include chest CT findings of bilateral patchy infiltrates and a "ground glass" pattern, coupled with biopsy and autopsy findings raise an important question about the lungs as a primary source of Covid-19associated coagulopathy.

Consider the following well recognized properties and characteristics of the lungs under normal and pathological conditions (reviewed in Moldoveanu [72]. First, being a primary portal for entry of pathogens the lungs have robust innate (non-specific) and adaptive (specific) immunity potential and reserve. Epithelial cells secrete mucins, defensins, lactoferrin and nitric oxide as an early defense. They also secrete IL- $1 \beta$, tumor necrosis factor (TNF)- $\alpha$, granulocyte-macrophage colony stimulating factor (GMCSF) and platelet activating factor to recruit inflammatory cells. Second, dendritic cells and macrophages line the respiratory tree where they present and phagocytose pathogens and also secrete chemokines, cytokines and other inflammatory mediators. Third, lymphocytes are present throughout the airways and lung parenchyma. T cells provide cellmediated immunity and $\beta$-cells are responsible for human immune responses by synthesizing antibodies. Forth, neutrophils are recruited rapidly to sites of infection or injury where they migrate from capillaries into alveolar and interstitial spaces. NETs, as previously described have platelet and contact protease activating potential, complex with histones that have cytotoxic effects and, in addition, produce DNA-myeloperoxidase complexes that can enter the circulation and exert proinflammatory and prothrombotic effects "at a distance" from the initial cluster [46]. Viral infections typically activate the innate immune system through toll-like receptors (TLRs) that recognize molecular patterns (pathogen-associated molecular patterns or PAMPs) [73]. T helper cells produce IF- $\gamma$.
Among the most important functional roll held by the lungs during infection is regulation of inflammatory responses and maintenance of systemic homeostasis. Continued activation of TLRs exerts a negative feedback loop through ILs and TGF- $\beta$ that down-regulates proinflammatory cytokine production and resulting inflammatory responses [74]. In addition, neural-immune interactions may contribute to suppressing inflammatory signals [75]. A failure to down-regulate or control the needed intensity of inflammation is a common observation in fatal Covid-19 infection.

Among the most consistent, yet unexpected findings at autopsy among decedents of COVID-19 is extramedullary megakaryocytes within the microvessels serving most major organs, including the lungs. Might there be a connection to Covid-19 pneumonia? Is there a possible connection to Covid-19-associated coagulopathy?

Megakaryocytes circulate through the pulmonary microcirculation and release platelets in a dynamic fashion [76]. The bone marrow is the site of origin for pulmonary megakaryocites and, while anchored within the pulmonary vascular can contribute substantially to platelet biogenesis. Pulmonary megakaryocytes and haematopoietic progenitor cells can migrate to and repopulate bone marrow stores.

The density of pulmonary megakaryocytes increases with infection, impaired lung function, cardiovascular disease and circulatory compromise [77]. Increased pulmonary thrombopoies is observed in patients with acute lung injury and ARDS (reviewed in Weyrich) [78] and activated platelets themselves can contribute to further injury. The number of circulating megakaryocytes is determined by pulmonary and systemic conditions. The available evidence suggests that $\sim 90 \%$ of intact megakaryocytes of pulmonary origin remain in the microcirculation of the lungs; however, an increased proportion can leave and enter the arterial circulation in the presence of lung infection and inflammation [79]. Platelet production from megakaryocytes in the peripheral circulation can occur.

The high density of entrapped neutrophils in the lungs of Covid-19 decedents described by Fox et al. [9] could represent a proinflammatory and prothrombotic manufacturing plant that produces in a poorly regulated state the conditions necessary and sufficient for Covid-19-associated coagulopathy.

The profound cytokine response observed in critically ill patients with Covid-19 and similarities with secondary HLH or macrophage activation syndrome raise the possibility that drugs designed to inhibit one or more pathogenic cytokines in the lungs may have both local and systemic benefit. Several targets for treatment include IL $1 \beta$ (canakinumab), IL6 (tocilizumab), (TNF)- $\alpha$ (infliximab) and (GMCSF) (lanzilumab) to name a few. While Covid-19 infection involves multiple organs, the initial infection in a majority 
of cases is pulmonary in origin. Accordingly, therapies that target early lung infections with the goal to minimize accelerating or escalating disease acuity, excessive immune response, hyper-inflammation, cytokine storm syndrome and systemic pathological effects may have a favorable effect on the initiation and steady progression of Covid-19-associated coagulopathy. This hypothesis will require testing-ideally, in the form of prospectively designed substudies of ongoing clinical trials targeting SARS-CoV-2 and its associated cytotoxic and heightened inflammatory properties.

\section{Distinguishing laboratory features of Covid-19-associated Coagulopathy}

A consistent observation among patients with Covid-19, particularly those with severe illness is an elevation of D-dimer in the peripheral blood (reviewed in Becker) [80]. The large case series of patients with COVID-19 $(n=5700)$ in the New York City area included baseline measures of D-dimer [81]. The median level was $438 \mathrm{ng} / \mathrm{ml}$ (IQR: 262-872 ng/ $\mathrm{ml}$ ) (Reference normal range [0-229 ng/ml]).

$\mathrm{D}$-dimer is a degradation product of fibrin, formed as a result of the conversion of fibrinogen to fibrin employing thrombin as a catalyst. The presence of D-dimer in the circulation signals the breakdown of fibrin polymers by plasmin. The terminology of D-dimer is based on its containment of two D-fragments of fibrin joined by a cross-link (factor XIII). While the presence of D-dimer within the peripheral circulation supports existing thrombus and correlates directly with the burden of fibrin that subsequently undergoes lysis, it does not specify the site(s) of thrombus.

The well-characterized pathogenesis and diagnosis of disseminated intravascular coagulation (DIC) are relevant for a discussion of Covid-19-associated coagulopathy [82]. DIC is recognized for its contribution to multi-organ system failure caused by platelet-fibrin thrombi in the microvasculature and concomitant bleeding phenotype caused by consumption of coagulation factors and thrombocytopenia. A common underlying theme that is believed to be responsible for DIC is systemic inflammation, the presence of and exposure of circulating coagulation proteins to tissue factor and diffuse vascular endothelial cell injury/dysfunction with critical loss of physiologic anticoagulants and fibrinolytic proteins, including tissue plasminogen activator and urokinase-like plasminogen activator.

Fibrin(ogen) degradation products, including D-dimer cause platelet activation [83, 84]. There is a direct correlation between the mass of FDPs and the degree of platelet activation. Platelet glycoprotein VI, in its dimeric form, binds to both collagen (in the early stage of thrombosis), fibrin D fragment and D-dimer facilitating platelet aggregation at sites of fibrin formation [85]. In fact, platelet GPVI may serve as receptor for polymerized fibrin that amplifies thrombin generation and recruits additional circulating platelets to the site of thrombus development.

The unique nature of Covid-19-associated coagulopathy and thrombophilia was underscored in a small case series by Panigada et al. [86]. A total of 24 laboratory-confirmed patients was included. Employing whole blood thromboelastography (TEG) features of heightened coagulation parameters were identified (decreased $\mathrm{R}$ [time to fibrin formation] and $\mathrm{K}$ [time to $20 \mathrm{~mm}$ clot] values and increased $\mathrm{K}$ angle [speed to clot, $20 \mathrm{~mm}$ ] and MA [clot strength]).

The available evidence derived from clinical observations and autopsy series distinguish Covid-19-associated coagulopathy from thrombotic microangiopathy and DIC. Potential overlaps can be observed in critically ill patients in whom circulatory collapse, multi-organ system failure, refractory hypoxemia and ARDS cause full-blown DIC.

\section{Thrombotic microangiopathy}

The prototypical features of thrombotic microangiopathy are Coomb's negative hemolytic anemia, thrombocytopenia and microvascular platelet thrombi. The most common disorders associated with thrombotic microangiopathy are thrombotic thrombocytopenia purpura (TTP) and hemolytic uremia syndrome (HUS). Organ dysfunction involving kidneys, brain and gastrointestinal tract is the result of impaired perfusion. There are primary and secondary causes of TTP and HUS. Secondary causes of TTP include infections (viral, bacterial), pregnancy, collagen-vascular diseases and drugs. Secondary causes of HUS include infections (most commonly enteric pathogens), solid organ and bone marrow transplant recipients, drugs and pregnancy. Thrombotic microangiopathy is a well-described complication of preeclampsia and eclampsia. The typical laboratory features of thrombotic microangiopathy include anemia (with schistocytes, reticulocytosis, plasma free hemoglobin, elevated LDH and decreased haptoglobin), and thrombocytopenia. In TTP, VWF cleaving protease levels are low. The pathological features include disseminated arteriolar and capillary thrombi consisting of aggregated platelets, VWF and fibrin with adjacent vascular endothelial cell swelling. Bleeding is not common in thrombotic microangiopathy.

\section{Disseminated intravascular coagulation}

DIC is recognized as a syndrome that complicates a variety of diseases and conditions with systemic activation of coagulation leading to thrombotic obstruction of small and less commonly medium-sized blood vessels. Unlike microangiopathies and Covid-19-associated coagulopathy, bleeding can dominate the clinical phenotype of DIC. In addition to activation of coagulation proteins, tissue factor and vascular 
endothelial cells, DIC is associated with activation of the fibrinolytic system, reduced endothelial cell surface proteases (antithrombin, protein C) and thrombocytopenia. The most common causes of DIC are severe infection, sepsis, major trauma, malignancy (acute or chronic DIC), complications of pregnancy, toxin exposures, severe allergic reactions and immunologic reactions (e.g. blood product transfusion).

The laboratory features of DIC vary widely depending on the stage encountered. In early DIC, there is compensated activation of the hemostatic system, however with progression to decompensated hemostatic activation, characteristic findings are observed. These include thrombocytopenia, increased PT and PTT, elevated fibrin(ogen) degradation products and decreased protease inhibition. Fibrinogen levels vary, however, in advanced stages of DIC fibrinogen levels decrease. VWF and factor VIII levels are typically increased from endothelial cell activation, but historically they are not elevated to the degree currently being observed in Covid-19-associated coagulopathy (Table 1).

\section{Guidelines and consensus statements}

The International Society on Thrombosis and Haemostasis published an interim guidance statement for the recognition and management of coagulopathy in Covid-19 [87]. The document highlights several key factors, including

Table 1 Distinguishing laboratory features of disseminated intravascular coagulation, thrombotic microangiopathy and Covid-19- associated coagulopathy

\begin{tabular}{llll}
\hline & DIC & Microangiopathy & Covid-19 \\
\hline PT & $\uparrow \uparrow$ & $\leftrightarrow$ & $\uparrow \uparrow$ \\
PTT & $\uparrow \uparrow$ & $\leftrightarrow$ & $\uparrow$ \\
Fibrinogen & $\downarrow$ & $\leftrightarrow$ & $\uparrow \uparrow$ \\
FDPs & $\uparrow \uparrow$ & $\leftrightarrow$ & $\uparrow \uparrow$ \\
D-dimer & $\uparrow$ & $\leftrightarrow$ & $\uparrow \uparrow$ or $\uparrow+$ \\
Platelet count & $\downarrow \downarrow$ & $\downarrow$ & $\uparrow$ or $\leftrightarrow$ \\
Peripheral blood & + & ++ & + \\
$\quad$ Smear ++ & & $\leftrightarrow$ & $\uparrow \uparrow$ \\
VWF & $\uparrow \uparrow$ & $\leftrightarrow$ & $\leftrightarrow$ \\
ADAMTS 13 & & $\downarrow$ & $\uparrow$ \\
AT & $\downarrow$ & $\downarrow$ & + \\
ACA & $\leftrightarrow$ & $\leftrightarrow$ & + \\
PC & $\downarrow$ & $\leftrightarrow$ & \\
\hline
\end{tabular}

$+\geq 6$ times the ULN

++ peripheral blood smear containing fragmented red blood cells

$P T$ prothrombin time, APTT activated partial thromboplastin time, FDPs fibrin(ogen) degradation products, VWF von Willebrand Factor, ADAMTS-13 a disintegrin and metalloproteinase with a thrombospondin type 1 motif, member, $A T$ antithrombin, $A C A$ anticardiolipin antibodies, $P C$ protein $\mathrm{C}$ an elevated D-dimer and its association with poor clinical outcomes, lack of thrombocytopenia, and late onset DIC in some patients. The recommendation for treatment calls for LMWH administered at prophylaxis doses pending the emergence of additional data.

The British Society of Hematology has recommended use of the ISTH DIC score $[88,89]$ as a prognostic indicator in patients with Covid-19 to guide treatment. Specifically in the absence of a bleeding phenotype, therapeutic doses of anticoagulants should be considered; however, prophylactic doses of either unfractionated heparin or LMWH are recommended (https://b-s-h.org.uk).

The American Society of Hematology has recommended thromboprophylaxis with either LMWH or fondaparinux (suggested over UFH to reduce patient contact) unless the risk of bleeding exceeds the risk of thrombosis. Dose adjustment for obesity should be considered. In patients with a contraindication for anticoagulation, pneumatic compression devices should be used (April 17, 2020 www.ash.com). Post-discharge thromboprophylaxis in patients with Covid19 using a regulatory agency approved regimen (betrixaban $160 \mathrm{mg}$ as a first dose, followed by $80 \mathrm{mg}$ daily for $35-42$ days or rivaroxaban $10 \mathrm{mg}$ daily for $31-39$ days) is favored.

The American College of Cardiology [90] recommended pharmacological VTE prophylaxis in Covid-19 patients requiring ICU-level care as well as those with pneumonia, respiratory failure or other comorbid factors such as heart failure, cancer, prolonged periods of immobility, and possibly pregnant women who are hospitalized. Extended postdischarge prophylaxis was considered reasonable for high risk patients (reduced mobility, co-morbid factors such as active cancer and possibly an elevated D-dimer at the time of discharge).

A consensus statement from several national Chinese societies and working groups [91] highlighted the importance of thromboprophylaxis and vigilant monitoring for thrombotic complications among patients with Covid-19 infection.

The Anticoagulation Forum (ACF) has recently drafted a guidance document for anticoagulation management employing case-based scenarios for patients with Covid-19 requiring hospitalization as well as for patients with indications for anticoagulation who are at risk for infection.

\section{Clinical trials of anticoagulant therapy in patients with Covid-19 infection}

At the time of this writing, there were eight clinical trials of anticoagulation in patients with Covid-19 registered on Clinicaltrials.gov. Two of the trials are actively recruiting. A majority of the trials are designed to compare traditional 
prophylactic VTE doses of LMWH with higher doses or treatment doses. One of the trials is designed to study patients with acute coronary syndrome as a complication of Covid-19 infection and includes aspirin, clopidogrel and rivaroxaban ( $2.5 \mathrm{mg}$ twice daily). The proposed sample size is 3170 participants.

\section{Anticoagulation and hemostasis agent decisions}

The acuity of illness in some patients with Covid-19 pneumonia complicated by end-organ injury (liver, kidneys), coupled by the administration of a wide-variety of medications that may include anti-viral and anti-inflammatory agents should alert clinicians, pharmacists and other health care providers to potential drug-drug interactions and drugrelated adverse effects (reviewed in Hermans) [92]. Careful consideration of drug and dose selection and close observation is particularly important for patients that have inherited disorders of hemostasis, hemophilia A, hemophilia B and Von Willebrand disease who require regular replacement therapy. In addition to developing specific management algorithms for patients with Covid-19, the ever-changing landscape created by the pandemic has and will likely continue to impact the drug and equipment supply chain, access to coagulation monitoring, laboratories and pharmacies. Under these circumstances, anticoagulants that do not require regular laboratory monitoring or the use of point-of-care testing and remote coagulation management are favored. Disorders of hemostasis, under ideal circumstances, would be treated with longer half-life replacement products, including those that can be administered subcutaneously.

\section{Conclusions and future directions}

Covid-19 infections are characterized by widely variable phonotypic expressions that involve most major organs and organ systems. An acquired syndrome known as Covid19-associated coagulopathy has emerged and proven itself to be common, multifactorial with involvement of the venous, arterial and microcirculatory systems and distinct from other viral illnesses. The available information distinguishes Covid-19-associated coagulopathy from DIC and thrombotic microangiopathy in its early stages and while anticoagulant therapy for thromboprophylaxis has been recommended by all major societies in the fields of cardiology, hematology and thrombosis optimal treatment has not yet been established through rigorously conducted clinical trials.

While many unanswered questions remain, the etiology of Covid-19-associated coagulopathy appears to follow Virchow's Triad (Fig. 5). The inclusion of thrombosis substudies in ongoing clinical trials of anti-viral, anti-inflammatory and immune-modulating therapies is strongly encouraged

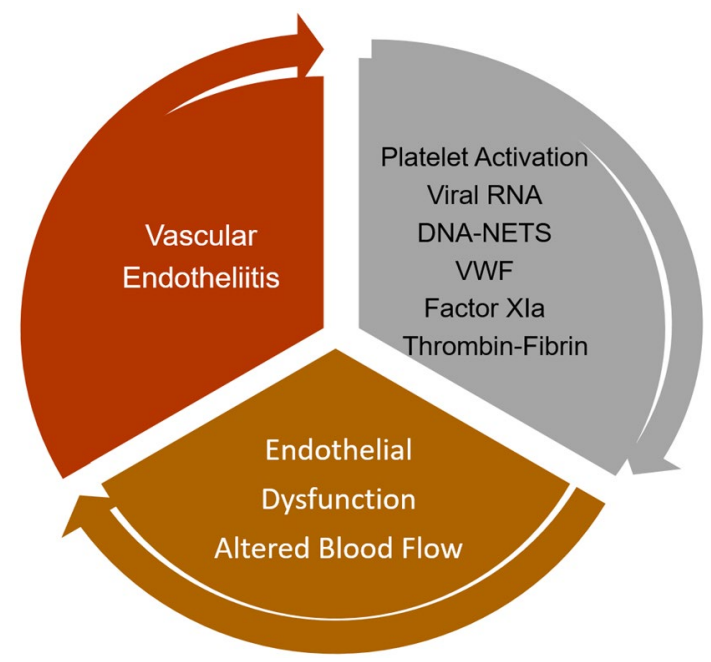

Fig. 5 Virchow's Triad represents a fundamental construct in which three components interact to establish an environment favoring or provoking thrombosis. They include abnormalities of the blood vessel wall or endothelial surface, altered blood flow and prothrombotic constituents within the circulating blood. In Covid-19-associated coagulopathy there is wide-scale endothelial cell inflammation and dysfunction, abnormal flow dynamics and activated platelets, high concentrations of von Willebrand Factor, cell free DNA, histones and viral RNA that collectively cause factor XI activation, thrombin generation and fibrin formation

as are dedicated studies targeting pathobiology-based targets that could include NETs, VWF, platelets and factor XI among others.

\section{References}

1. Klok FA, Kruip MJHA, van der Meer NJM, Arbous MS, Gommers DAMPJ, Kant KM, Kaptein FHJ, van Paassen J, Stals MAM, Huisman MV, Endeman H (2020) Incidence of thrombotic complications in critically ill ICU patients with COVID-19. Thromb Res. On-line April10

2. Tang N, Li D, Wang X, Sun Z (2020) Abnormal coagulation parameters are associated with poor prognosis in patients with novel coronavirus pneumonia. J Thromb Haemost JTH 18:844-847

3. Tang N, Bai H, Chen X, Gong J, Li D, Sun Z (2020) Anticoagulant treatment is associated with decreased mortality in severe coronavirus disease 2019 patients with coagulopathy. J Thromb Haemost 18:1094-1099

4. Helms $\mathbf{J}$ (2020) High risk of thrombosis in patients in severe SARS-CoV-2 infection: a multicenter propspective cohort study. J Intensive Care Med. https://doi.org/10.1007/s00134-020-06062

5. Leonard-Lorant I, Delabranche X, Severac F, Helms J, Pauzet C, Collange O, Schneider F, Labani A, Bilbault P, Moliere S, Leyendecker P, Roy C, Ohana M (2020) Acute pulmonary embolism in COVID-19 patients on CT angiography and relationship to D-dimer levels. Radiology. https://doi.org/10.1148/radiol.20202 01561

6. Oxley TJ, Mocco J, Majidi S, Kellner CP, Shoirah H, Singh IP, De Leacy RA, Shigematsu T, Ladner TR, Yaeger KA, Skliut M, 
Weinberger J, Dangayach NS, Bederson JB, Tuhrim S, Fifi JT (2020) Large-vessel stroke as a presenting feature of Covid-19 in the young. New Engl J Med. https://doi.org/10.1056/NEJMc2009787

7. Zhou P, Yang XL, Wang XG, Hu B, Zhang L, Zhang W, Si HR, Zhu Y, Li B, Huang CL, Chen HD, Chen J, Luo Y, Guo H, Jiang RD, Liu MQ, Chen Y, Shen XR, Wang X, Zheng XS, Zhao K, Chen QJ, Deng F, Liu LL, Yan B, Zhan FX, Wang YY, Xiao GF, Shi ZL (2020) A pneumonia outbreak associated with a new coronavirus of probable bat origin. Nature 579:270-273

8. Zhou F, Yu T, Du R, Fan G, Liu Y, Liu Z, Xiang J, Wang Y, Song B, Gu X, Guan L, Wei Y, Li H, Wu X, Xu J, Tu S, Zhang Y, Chen H, Cao B (2020) Clinical course and risk factors for mortality of adult inpatients with COVID-19 in Wuhan, China: a retrospective cohort study. Lancet 395(10229):1054-1062

9. Fox SE, Akmatbekov A, Harbert JL, Li G, Brown JQ, Vander Heide RS (2020) Pulmonary and cardiac pathology in Covid-19: the first autopsy series from New Orleans. medRxiv. https://doi. org/10.1101/2020.04.06.20050575

10. Becker RC (2020) Toward understanding the 2019 Coronavirus and its impact on the heart. J Thromb Thrombolysis. https://doi. org/10.1007/s11239-020-02107-6

11. Hamming I, Timens W, Bulthuis M, Lely A, Navis G, van Goor H (2004) Tissue distribution of ACE2 protein, the functional receptor for SARS coronavirus. A first step in understanding SARS pathogenesis. J Pathol 203:631-637

12. Wu XX, Zhao LZ, Tang SJ, Weng TH, Wu WG, Yao SH, Wu HB, Cheng LF, Wang J, Hu FY, Wu NP, Yao HP, Zhang FC, Li LJ (2020) Novel pathogenic characteristics of highly pathogenic avian influenza virus H7N9: viraemia and extrapulmonary infection. Emerg Microb Infect 8:1-39

13. Wu F, Zhao S, Yu B, Chen YM, Wang W, Song ZG, Hu Y, Tao ZW, Tian JH, Pei YY, Yuan ML, Zhang YL, Dai FH, Liu Y, Wang QM, Zheng JJ, Xu L, Holmes EC, Zhang YZ (2020) A new coronavirus associated with human respiratory disease in China. Nature 579:265-269

14. Zheng S, Fan J, Yu F, Feng B, Lou B, Zou Q, Xie G, Lin S, Wang R, Yang X, Chen W, Wang Q, Zhang D, Liu Y, Gong R, Ma Z, Lu S, Xiao Y, Gu Y, Zhang J, Yao H, Xu K, Lu X, Wei G, Zhou J, Fang Q, Cai H, Qiu Y, Sheng J, Chen Y, Liang T (2020) Viral load dynamics and disease severity in patients infected with SARS-CoV-2 in Zhejiang province, China, January-March 2020: retrospective cohort study. BMJ 369:m1443

15. Hu X, Xing Y, Jia J, Ni W, Liang J, Zhao D, Song X, Gao R, Jiang F (2020) Factors associated with negative conversion of viral RNA in patients hospitalized with COVID-19. Sci Total Environ 728:138812

16. Chen W, Lan Y, Yuan X, Deng X, Li Y, Cai X, Li L, He R, Tan Y, Deng X, Gao M, Tang G, Zhao L, Wang J, Fan Q, Wen C, Tong Y, Tang Y, Hu F, Li F, Tang X (2020) Detectable 2019-nCoV viral RNA in blood is a strong indicator for the further clinical severity. Emerg Microb Infect 9:469-473

17. Hirschi KK, D'Amore PA (1996) Pericytes in the microvasculature. Cardiovasc Res 32:687-698

18. Sims DE (2000) Diversity within pericytes. Clin Exp Pharmacol Physiol 27:842-846

19. Magro C, Mulvey JJ, Berlin D, Nuovo G, Salvatore S, Harp J, Baxter-Stoltzfus A, Laurence J (2020) Complement associated microvascular injury and thrombosis in the pathogenesis of severe COVID-19 infection: a report of five cases. Transl Res. https://doi. org/10.1016/j.trs1.2020.04.007

20. Barnes BJ, Adrover JM, Baxter-Stoltzfus A, Borczuk A, CoolsLartigue J, Crawford JM, Dassler-Plenker J, Guerci P, Huynh C, Knight JS, Loda M, Looney MR, McAllister F, Rayes R, Renaud S, Rousseau S, Salvatore S, Schwartz RE, Spicer JD, Yost CC, Weber A, Zuo Y, Egeblad M (2020) Targeting potential drivers of COVID-19: neutrophil extracellular traps. J Exp Med. https:// doi.org/10.1084/jem.20200652

21. Monteil V, Kwon H, Prado P, Hagelkruys A, Wimmer RA, Stahl M, Leopoldi A, Garreta E, Hurtado Del Pozo C, Prosper F, Romero JP, Wirnsberger G, Zhang H, Slutsky AS, Conder R, Montserrat N, Mirazimi A, Penninger JM (2020) Inhibition of SARS-CoV-2 infections in engineered human tissues using clinical-grade soluble human ACE2. Cell. https://doi.org/10.1016/j. cell.2020.04.004

22. Varga Z, Flammer AJ, Steiger P, Haberecker M, Andermatt R, Zinkernagel AS, Mehra MR, Schuepbach RA, Ruschitzka F, Moch H (2020) Endothelial cell infection and endotheliitis in COVID-19. The Lancet. https://doi.org/10.1016/S0140 $-6736(20) 30937-5$

23. Sharma A, Garcia G, Arumugaswami V, Svendsen CN (2020) Human iPSC-derived cardiomyocytes are susceptible to SARSCoV-2 infection. bioRxiv. 2020:2020.04.21.051912

24. Willicombe M, Moss J, Moran L, Brookes P, Santos-Nunez E, McLean AG, Cairns T, Taube D, Cook TH, Roufosse C (2016) Tubuloreticular inclusions in renal allografts associate with viral infections and donor-specific antibodies. J Am Soc Nephrol 27:2188-2195

25. Jumic S, Nand S (2019) Hemophagocytic lymphohistiocytosis in adults: associated diagnoses and outcomes, a ten-year experience at a single institution. J Hematol (Brossard) 8:149-154

26. Mehta P, McAuley DF, Brown M, Sanchez E, Tattersall RS, Manson JJ (2020) COVID-19: consider cytokine storm syndromes and immunosuppression. Lancet 395:1033-1034

27. McGonagle D, Sharif K, O'Regan A, Bridgewood C (2020) The role of cytokines including interleukin-6 in COVID-19 induced pneumonia and macrophage activation syndrome-like disease. Autoimmun Rev 102537.

28. Pick R, Begandt D, Stocker TJ, Salvermoser M, Thome S, Bottcher RT, Montanez E, Harrison U, Forne I, Khandoga AG, Coletti R, Weckbach LT, Brechtefeld D, Haas R, Imhof A, Massberg S, Sperandio M, Walzog B (2017) Coronin 1A, a novel player in integrin biology, controls neutrophil trafficking in innate immunity. Blood 130:847-858

29. Becker RC, Sexton T, Smyth SS (2018) Translational implications of platelets as vascular first responders. Circ Res 122:506-522

30. Fitzgerald JR, Foster TJ, Cox D (2006) The interaction of bacterial pathogens with platelets. Nat Rev Microbiol 4:445-457

31. Loughman A, Fitzgerald JR, Brennan MP, Higgins J, Downer R, Cox D, Foster TJ (2005) Roles for fibrinogen, immunoglobulin and complement in platelet activation promoted by Staphylococcus aureus clumping factor A. Mol Microbiol 57:804-818

32. Guo L, Rondina MT (2019) The era of thromboinflammation: platelets are dynamic sensors and effector cells during infectious diseases. Front Immunol 10:2204

33. Moreau D, Timsit JF, Vesin A, Garrouste-Orgeas M, de Lassence A, Zahar JR, Adrie C, Vincent F, Cohen Y, Schlemmer B, Azoulay E (2007) Platelet count decline: an early prognostic marker in critically ill patients with prolonged ICU stays. Chest 131:1735-1741

34. Brill A, Fuchs TA, Savchenko AS, Thomas GM, Martinod K, De Meyer SF, Bhandari AA, Wagner DD (2012) Neutrophil extracellular traps promote deep vein thrombosis in mice. J Thromb Haemost 10:136-144

35. Thalin C, Daleskog M, Goransson SP, Schatzberg D, Lasselin J, Laska AC, Kallner A, Helleday T, Wallen H, Demers M (2017) Validation of an enzyme-linked immunosorbent assay for the quantification of citrullinated histone $\mathrm{H} 3$ as a marker for neutrophil extracellular traps in human plasma. Immunol Res 65:706-712 
36. Yipp BG, Petri B, Salina D, Jenne CN, Scott BN, Zbytnuik LD, Pittman K, Asaduzzaman M, Wu K, Meijndert HC, Malawista SE, de Boisfleury CA, Zhang K, Conly J, Kubes P (2012) Infectioninduced NETosis is a dynamic process involving neutrophil multitasking in vivo. Nat Med 18:1386-1393

37. Clark SR, Ma AC, Tavener SA, McDonald B, Goodarzi Z, Kelly MM, Patel KD, Chakrabarti S, McAvoy E, Sinclair GD, Keys EM, Allen-Vercoe E, Devinney R, Doig CJ, Green FH, Kubes P (2007) Platelet TLR4 activates neutrophil extracellular traps to ensnare bacteria in septic blood. Nat Med 13:463-469

38. Jahr S, Hentze H, Englisch S, Hardt D, Fackelmayer FO, Hesch RD, Knippers R (2001) DNA fragments in the blood plasma of cancer patients: quantitations and evidence for their origin from apoptotic and necrotic cells. Can Res 61:1659-1665

39. Nakazawa F, Kannemeier C, Shibamiya A, Song Y, Tzima E, Schubert U, Koyama T, Niepmann M, Trusheim H, Engelmann B, Preissner KT (2005) Extracellular RNA is a natural cofactor for the (auto-)activation of factor VII-activating protease (FSAP). Biochem J 385:831-838

40. Kannemeier C, Shibamiya A, Nakazawa F, Trusheim H, Ruppert C, Markart P, Song Y, Tzima E, Kennerknecht E, Niepmann M, von Bruehl ML, Sedding D, Massberg S, Gunther A, Engelmann B, Preissner KT (2007) Extracellular RNA constitutes a natural procoagulant cofactor in blood coagulation. Proc Natl Acad Sci USA 104:6388-6393

41. Gajsiewicz JM, Smith SA, Morrissey JH (2017) Polyphosphate and RNA differentially modulate the contact pathway of blood clotting. J Biol Chem 292:1808-1814

42. Baker CJ, Smith SA, Morrissey JH (2019) Polyphosphate in thrombosis, hemostasis, and inflammation. Res Prac Thromb Haemost 3:18-25

43. Wang Y, Luo L, Braun OO, Westman J, Madhi R, Herwald H, Morgelin M, Thorlacius H (2018) Neutrophil extracellular trapmicroparticle complexes enhance thrombin generation via the intrinsic pathway of coagulation in mice. Sci Rep 8:4020

44. Wang Y, Gao H, Shi C, Erhardt PW, Pavlovsky A, Soloviev DA, Bledzka K, Ustinov V, Zhu L, Qin J, Munday AD, Lopez J, Plow E, Simon DI (2017) Leukocyte integrin Mac-1 regulates thrombosis via interaction with platelet GPIbalpha. Nat Commun 8:15559

45. Wang Y, Li M, Stadler S, Correll S, Li P, Wang D, Hayama $\mathrm{R}$, Leonelli L, Han H, Grigoryev SA, Allis CD, Coonrod SA (2009) Histone hypercitrullination mediates chromatin decondensation and neutrophil extracellular trap formation. J Cell Biol 184:205-213

46. Li B, Liu Y, Hu T, Zhang Y, Zhang C, Li T, Wang C, Dong Z, Novakovic VA, Hu T, Shi J (2019) Neutrophil extracellular traps enhance procoagulant activity in patients with oral squamous cell carcinoma. J Cancer Res Clin Oncol 145:1695-1707

47. Zuo Y, Yalavarthi S, Shi H, Gockman K, Zuo M, Madison JA, Blair CN, Weber A, Barnes BJ, Egeblad M, Woods RJ, Kanthi Y, Knight JS (2020) Neutrophil extracellular traps in COVID-19. JCI Insight. https://doi.org/10.1172/jci.insight.138999

48. Pitchford S, Pan D, Welch HC (2017) Platelets in neutrophil recruitment to sites of inflammation. Curr Opin Hematol 24:23-31

49. Thornton P, McColl BW, Greenhalgh A, Denes A, Allan SM, Rothwell NJ (2010) Platelet interleukin-1alpha drives cerebrovascular inflammation. Blood 115:3632-3639

50. van Gils JM, da Costa Martins PA, Mol A, Hordijk PL, Zwaginga JJ (2008) Transendothelial migration drives dissociation of plateletmonocyte complexes. Thromb Haemost 100:271-279

51. Grassle S, Huck V, Pappelbaum KI, Gorzelanny C, AponteSantamaria C, Baldauf C, Grater F, Schneppenheim R, Obser T, Schneider SW (2014) von Willebrand factor directly interacts with DNA from neutrophil extracellular traps. Arterioscler Thromb Vasc Biol 34:1382-1389
52. Clancy L, Beaulieu LM, Tanriverdi K, Freedman JE (2017) The role of RNA uptake in platelet heterogeneity. Thromb Haemost 117:948-961

53. Risitano A, Beaulieu LM, Vitseva O, Freedman JE (2012) Platelets and platelet-like particles mediate intercellular RNA transfer. Blood 119:6288-6295

54. Edelstein LC (2017) The role of platelet microvesicles in intercellular communication. Platelets 28:222-227

55. Oehmcke S, Morgelin M, Herwald H (2009) Activation of the human contact system on neutrophil extracellular traps. J Innate Immun 1:225-230

56. Elaskalani O, Abdol Razak NB, Metharom P (2018) Neutrophil extracellular traps induce aggregation of washed human platelets independently of extracellular DNA and histones. Cell Commun Signal CCS 16:24

57. Grasso S, Neumann A, Lang IM, Etscheid M, von KockritzBlickwede M, Kanse SM (2018) Interaction of factor VII activating protease (FSAP) with neutrophil extracellular traps (NETs). Thromb Res 161:36-42

58. Seif K, Alidzanovic L, Tischler B, Ibrahim N, Zagrapan B, Rauscher S, Salzmann M, Hell L, Mauracher LM, Budde U, Schmid JA, Jilma B, Pabinger I, Assinger A, Starlinger P, Brostjan C (2018) Neutrophil-mediated proteolysis of thrombospondin-1 promotes platelet adhesion and string formation. Thromb Haemost 118:2074-2085

59. Grechowa I, Horke S, Wallrath A, Vahl CF, Dorweiler B (2017) Human neutrophil elastase induces endothelial cell apoptosis by activating the PERK-CHOP branch of the unfolded protein response. FASEB J 31:3868-3881

60. Ruf W, Ruggeri ZM (2010) Neutrophils release brakes of coagulation. Nat Med 16:851-852

61. Higuchi DA, Wun TC, Likert KM, Broze GJ Jr (1992) The effect of leukocyte elastase on tissue factor pathway inhibitor. Blood 79:1712-1719

62. Goel MS, Diamond SL (2003) Neutrophil cathepsin G promotes prothrombinase and fibrin formation under flow conditions by activating fibrinogen-adherent platelets. J Biol Chem 278:9458-9463

63. Kolpakov V, D'Adamo MC, Salvatore L, Amore C, Mironov A, Iacoviello L, Donati MB (1994) Neutrophil derived cathepsin G induces potentially thrombogenic changes in human endothelial cells: a scanning electron microscopy study in static and dynamic conditions. Thromb Haemost 72:140-145

64. Gould TJ, Vu TT, Swystun LL, Dwivedi DJ, Mai SH, Weitz JI, Liaw PC (2014) Neutrophil extracellular traps promote thrombin generation through platelet-dependent and platelet-independent mechanisms. Arterioscler Thromb Vasc Biol 34:1977-1984

65. Carestia A, Rivadeneyra L, Romaniuk MA, Fondevila C, Negrotto S, Schattner M (2013) Functional responses and molecular mechanisms involved in histone-mediated platelet activation. Thromb Haemost 110:1035-1045

66. Semeraro F, Ammollo CT, Morrissey JH, Dale GL, Friese P, Esmon NL, Esmon CT (2011) Extracellular histones promote thrombin generation through platelet-dependent mechanisms: involvement of platelet TLR2 and TLR4. Blood 118:1952-1961

67. Brinkmann V (2018) Neutrophil extracellular traps in the second decade. J Innate Immun 10:414-421

68. Kolaczkowska E, Jenne CN, Surewaard BG, Thanabalasuriar A, Lee WY, Sanz MJ, Mowen K, Opdenakker G, Kubes P (2015) Molecular mechanisms of NET formation and degradation revealed by intravital imaging in the liver vasculature. Nat Commun 6:6673

69. Savchenko AS, Borissoff JI, Martinod K, De Meyer SF, Gallant M, Erpenbeck L, Brill A, Wang Y, Wagner DD (2014) VWFmediated leukocyte recruitment with chromatin decondensation 
by PAD4 increases myocardial ischemia/reperfusion injury in mice. Blood 123:141-148

70. Savchenko AS, Martinod K, Seidman MA, Wong SL, Borissoff JI, Piazza G, Libby P, Goldhaber SZ, Mitchell RN, Wagner DD (2014) Neutrophil extracellular traps form predominantly during the organizing stage of human venous thromboembolism development. J Thromb Haemost 12:860-870

71. Escher R, Breakey N, Lammle B (2020) Severe COVID-19 infection associated with endothelial activation. Thromb Res 190:62

72. Moldoveanu B, Otmishi P, Jani P, Walker J, Sarmiento X, Guardiola J, Saad M, Yu J (2009) Inflammatory mechanisms in the lung. J Inflamm Res 2:1-11

73. Wang JP, Kurt-Jones EA, Finberg RW (2007) Innate immunity to respiratory viruses. Cell Microbiol 9:1641-1646

74. Pittet JF, Griffiths MJ, Geiser T, Kaminski N, Dalton SL, Huang X, Brown LA, Gotwals PJ, Koteliansky VE, Matthay MA, Sheppard D (2001) TGF-beta is a critical mediator of acute lung injury. J Clin Investig 107:1537-1544

75. Tracey KJ (2002) The inflammatory reflex. Nature 420:853-859

76. Lefrancais E, Ortiz-Munoz G, Caudrillier A, Mallavia B, Liu F, Sayah DM, Thornton EE, Headley MB, David T, Coughlin SR, Krummel MF, Leavitt AD, Passegue E, Looney MR (2017) The lung is a site of platelet biogenesis and a reservoir for haematopoietic progenitors. Nature 544:105-109

77. Sharma GK, Talbot IC (1986) Pulmonary megakaryocytes: "missing link" between cardiovascular and respiratory disease? J Clin Pathol 39:969-976

78. Weyrich AS, Zimmerman GA (2013) Platelets in lung biology. Annu Rev Physiol 75:569-591

79. Hansson GK, Libby P, Schonbeck U, Yan ZQ (2002) Innate and adaptive immunity in the pathogenesis of atherosclerosis. Circ Res 91:281-291

80. Becker RC (2020) Covid-19 treatment update: follow the scientific evidence. J Thromb Thrombolysis. https://doi.org/10.1007/s1123 9-020-02120-9

81. Richardson S, Hirsch JS, Narasimhan M, Crawford JM, McGinn T, Davidson KW, Barnaby DP, Becker LB, Chelico JD, Cohen SL, Cookingham J, Coppa K, Diefenbach MA, Dominello AJ, DuerHefele J, Falzon L, Gitlin J, Hajizadeh N, Harvin TG, Hirschwerk DA, Kim EJ, Kozel ZM, Marrast LM, Mogavero JN, Osorio GA, Qiu M, Zanos TP (2020) Presenting characteristics, comorbidities, and outcomes among 5700 patients hospitalized with COVID19 in the New York City Area. JAMA. https://doi.org/10.1001/ jama.2020.6775

82. Gando S, Fujishima S, Saitoh D, Shiraishi A, Yamakawa K, Kushimoto S, Ogura H, Abe T, Mayumi T, Sasaki J, Kotani J, Takeyama N, Tsuruta R, Takuma K, Yamashita N, Shiraishi SI, Ikeda H, Shiino Y, Tarui T, Nakada TA, Hifumi T, Otomo Y, Okamoto K, Sakamoto Y, Hagiwara A, Masuno T, Ueyama M, Fujimi S, Umemura Y (2020) The significance of disseminated intravascular coagulation on multiple organ dysfunction during the early stage of acute respiratory distress syndrome. Thromb Res 191:15-21
83. Onselaer MB, Hardy AT, Wilson C, Sanchez X, Babar AK, Miller JLC, Watson CN, Watson SK, Bonna A, Philippou H, Herr AB, Mezzano D, Ariens RAS, Watson SP (2017) Fibrin and D-dimer bind to monomeric GPVI. Blood Adv 1:1495-1504

84. van der Vorm LN, Remijn JA, de Laat B, Huskens D (2018) Effects of plasmin on von Willebrand factor and platelets: a narrative review. TH Open 2:e218-e228

85. Induruwa I, Moroi M, Bonna A, Malcor JD, Howes JM, Warburton EA, Farndale RW, Jung SM (2018) Platelet collagen receptor glycoprotein VI-dimer recognizes fibrinogen and fibrin through their D-domains, contributing to platelet adhesion and activation during thrombus formation. J Thromb Haemost 16:389-404

86. Panigada M, Bottino N, Tagliabue P, Grasselli G, Novembrino C, Chantarangkul V, Pesenti A, Peyvandi F, Tripodi A (2020) Hypercoagulability of COVID-19 patients in intensive care unit. A report of thromboelastography findings and other parameters of hemostasis. J Thromb Haemost. https://doi.org/10.1111/jth.14850

87. Thachil J, Tang N, Gando S, Falanga A, Cattaneo M, Levi M, Clark C, Iba T (2020) ISTH interim guidance on recognition and management of coagulopathy in COVID-19. J Thromb Haemost 18:1023-1026

88. Taylor J (2012) ESC/EACTS Guidelines on the management of valvular heart disease. Eur Heart J 33:2371-2372

89. Kinasewitz GT, Zein JG, Lee GL, Nazir SA, Taylor FB Jr (2005) Prognostic value of a simple evolving disseminated intravascular coagulation score in patients with severe sepsis. Crit Care Med 33:2214-2221

90. Bikdeli B, Madhavan MV, Jimenez D, Chuich T, Dreyfus I, Driggin E, Nigoghossian CD, Ageno W, Madjid M, Guo Y, Tang LV, $\mathrm{Hu}$ Y, Giri J, Cushman M, Quéré I, Dimakakos EP, Gibson CM, Lippi G, Favaloro EJ, Fareed J, Caprini JA, Tafur AJ, Burton JR, Francese DP, Wang EY, Falanga A, McLintock C, Hunt BJ, Spyropoulos AC, Barnes GD, Eikelboom JW, Weinberg I, Schulman S, Carrier M, Piazza G, Beckman JA, Steg PG, Stone GW, Rosenkranz S, Goldhaber SZ, Parikh SA, Monreal M, Krumholz HM, Konstantinides SV, Weitz JI, Lip GYH (2020) COVID-19 and thrombotic or thromboembolic disease: implications for prevention, antithrombotic therapy, and follow-up. J Am Coll Cardiol. https://doi.org/10.1016/j.jacc.2020.04.031

91. Zhai Z, Li C, Chen Y, Gerotziafas G, Zhang Z, Wan J, Liu P, Elalamy I, Wang C (2020) Prevention and treatment of venous thromboembolism associated with coronavirus disease 2019 infection: a consensus statement before guidelines. Thromb Haemost. https://doi.org/10.1055/s-0040-1710019

92. Hermans C, Lambert C (2020) Impact of the COVID-19 pandemic on therapeutic choices in thrombosis-hemostasis. J Thromb Haemost. https://doi.org/10.1111/jth.14845

Publisher's Note Springer Nature remains neutral with regard to jurisdictional claims in published maps and institutional affiliations. 